\title{
A escrita do sismo: identidades fronteiriças em $O$ chão que ela pisa, de Salman Rushdie
}

\author{
Vívien Gonzaga e Silva \\ Doutoranda em Letras - Literatura Comparada / UFMG
}

\begin{abstract}
RESUMO
Com base na representação metafórica de fenômenos naturais de ordem sísmica, entendidos como índice analógico dos processos identitários configurados no espaço e tempo contemporâneos, analisa-se o romance $O$ chão que ela pisa, de Salman Rushdie, apontando para a formação de um "imaginário migrante" como espaço simbólico de filiação identitária.
\end{abstract}

PALAVRAS-CHAVE

Fronteira, terremoto, identidade

Que lembrança darei ao país que me deu tudo que lembro e sei, tudo quanto senti?

Na noite do sem-fim, breve o tempo esqueceu minha incerta medalha, e a meu nome se ri.

E mereço esperar mais do que os outros, eu? Tu não me enganas, mundo, e não te engano a ti.

Esses monstros atuais, não os cativa Orfeu, a vagar, taciturno, entre o talvez e o se.

Não deixarei de mim nenhum canto radioso, uma voz matinal palpitando na bruma e que arranque de alguém seu mais secreto espinho.

De tudo quanto foi meu passo caprichoso na vida, restará, pois o resto se esfuma, uma pedra que havia em meio do caminho.

Carlos Drummond de Andrade. Claro enigma.

Sétimo romance de Salman Rushdie, O chão que ela pisa foi editado em 1999. ${ }^{1}$ Grande parte das resenhas publicadas sobre o livro destaca a história de amor que se

\footnotetext{
${ }^{1}$ Além de vasta produção ensaística, contos, crônicas, literatura infanto-juvenil, e da organização de antologias literárias, Salman Rushdie publicou, até o momento, os romances Grimus (1975); Os
} 
desenrola, em suas 575 páginas, emaranhada ao mito de Orfeu. Esse intertexto não deve ser desconsiderado, porém, ao longo do enredo, esse fio narrativo esgarça-se em múltiplas pontas que, por sua vez, abrem diálogo com as mais diversas referências e discursos, criando uma densa rede de citações - o que, em certa medida, se pode reconhecer como marca da escrita desse autor indo-britânico.

Salman Rushdie é, até o momento, um escritor votado ao enciclopedismo. Seus romances recusam a concisão, a síntese, o sumário; são, em sentido inverso, extensos, prolixos, intrincados, e parecem propor-se ao que Jorge Luis Borges definiu como sendo "a tarefa de desenhar o mundo", num paciente labirinto de linhas. ${ }^{2}$ Nesse labirinto, o leitor é continuamente convidado a embrenhar-se em trilhas inumeráveis e, muitas vezes, tentado a seguir caminhos que, ao fim, se bifurcam, obrigando-o a fazer outras escolhas, a rever o percurso, a experimentar novas chaves. Tem-se, nessas incursões, a assustadora impressão de que, virtualmente, suas narrativas podem abarcar todas as esferas do conhecimento, aglutinando processos acumulados no tempo e no espaço históricos e, às vezes, pré-históricos, construindo-se a partir de meticulosa conjunção da experiência humana.

Contudo, seu desenho do mundo mostra-se como uma enciclopédia embaralhada, um arquivo em desarranjo, como um inventário desde sempre falho, incompleto, lacunar. Tratase, dessa maneira, de uma escrita que assume, sem subterfúgios, "o que há de desconcertante" na súbita contiguidade das coisas sem relação, como aponta Michel Foucault em sua interpretação da enciclopédia chinesa de Borges. ${ }^{3}$ Por isso mesmo, apresenta-se como espaço de coexistência, de mesclagem, de enredamento dos extremos culturais; constitui-se, assim, como aquela "região mediana" que se estabelece entre as palavras e as coisas; zona de contato reconhecida por Foucault e redefinida por Silviano Santiago como "solo único", comum ao olhar codificado do europeu e ao conhecimento reflexivo latino-americano ${ }^{4}$ ou, numa compreensão estendida, às culturas colonizadas e também às colonialistas - coisas designadas por palavras, como, por exemplo, América e Europa, Índia e Inglaterra, Oriente e Ocidente, barbárie e civilização.

filhos da meia-noite (1980); Vergonha (1983); Os versos satânicos (1989); Haroun e o mar de histórias (1990); O último suspiro do Mouro (1995); O chão que ela pisa (1999); Fúria (2001); Shalimar, o equilibrista (2005); A feiticeira de Florença (2008); e Luka e o fogo da vida (2010).

${ }^{2}$ BORGES. Obras completas, v. 2, p. 254.

${ }^{3} \mathrm{Cf}$. FOUCAULT. As palavras e as coisas, p. X.

${ }^{4}$ Cf. SANTIAGO. O cosmopolitismo do pobre: crítica literária e crítica cultural, p. 217. 
Esse solo comum, que, para Santiago, conforma-se através da linguagem literária e artística, é lavrado por Rushdie por meio da apropriação e mistura de inúmeros outros discursos - histórico, mítico, religioso, científico -, o que impõe que suas narrativas sejam lidas com um olhar multidirecional, buscando apreender as construções metafóricas, as ironias, os entrecruzamentos, as paródias, as remissões e os jogos intertextuais que marcam sua escrita. É nesse aspecto que Salman Rushdie parece enfrentar o que Italo Calvino, ao tratar da "multiplicidade" em suas propostas para a literatura deste milênio, define como sendo o desafio de "tecer em conjunto os diversos saberes e os diversos códigos numa visão pluralística e multifacetada do mundo". É possível, portanto, que a produção de Rushdie seja um bom exemplo do que Calvino identifica como uma "excessiva ambição de propósitos", condenável em muitos campos da atividade humana, mas de modo algum na literatura, cuja vitalidade estaria justamente na disposição de poetas e escritores de "se lançarem a empresas que ninguém mais ousaria imaginar". Nesse sentido, a multiplicidade estaria na base do universo ficcional de Rushdie, compondo "infinitas relações de tudo com tudo", e explicitando certa vocação do romance contemporâneo para constituir-se como "método de conhecimento, e principalmente como rede de conexões entre os fatos, entre as pessoas, entre as coisas do mundo". 5

A ideia de rede que parece permear o projeto escritural de Salman Rushdie torna-se útil também quando se pretende abordar os processos identitários que se apresentam na contemporaneidade como formas de subjetivação sempre dirigidas por uma inevitável permuta de posições, conformando identidades extremamente complexas. De acordo com uma declaração do autor, por ocasião do lançamento de Os versos satânicos, em 1989, sua escrita "celebra a hibridez, a impureza, a entremesclagem, a transformação que resulta de uma combinação nova e inesperada de seres humanos, culturas, idéias, política, filmes, canções" 6 Percebe-se, em suas narrativas, que tal celebração somente se mostra possível a partir de um celebrante também híbrido, impuro, compósito, ou seja, de um "homem traduzido", como ele mesmo se define. ${ }^{7}$ Esse ser traduzido, necessariamente portador de uma identidade múltipla, ambivalente, rasurada, reflexo de um pertencimento simultâneo a culturas distintas, parece

\footnotetext{
${ }^{5}$ Cf. CALVINO. Seis propostas para o próximo milênio, p. 115-138.

${ }^{6}$ Cf. RAJAGOPALAN. Quando o humor azeda: o episódio Rushdie em retrospectiva, p. 119.

${ }^{7}$ Essa expressão, cunhada na coletânea de ensaios do autor, Imaginary homelands, de 1992, remete a uma ambivalência identitária experimentada pelo autor. Nascido na cidade de Bombaim - atual Mumbai -, em 1947, Salman Rushdie transferiu-se, treze anos mais tarde, para a Inglaterra. Atualmente, cidadão britânico, recentemente condecorado com o título de "cavaleiro", pela Rainha Elizabeth II, mora em Nova York.
} 
repercutir na constituição dos protagonistas de seus romances, concebidos, em sua maioria, como migrantes de origem indiana, exilados, criaturas errantes que não conseguem fixar raízes em lugar algum.

É isso o que caracteriza, em O chão que ela pisa, os indianos Rai Merchant e Ormus Cama, e a norte-americana Vina Apsara, personagens com trajetórias delineadas pelo contínuo deslocamento, e que desconhecem as barreiras e os limites geográficos do planeta, colocando em cena uma face melancólica da condição nômade, marcada não apenas pelo trânsito ininterrupto, mas, principalmente, pela alternância entre mundos distintos. Constantemente postos em movimento pelas contingências que marcam suas histórias pessoais, parecem destinados a cruzar limites, a ultrapassar as fronteiras entre Oriente e Ocidente, entre Europa e América, entre o território político dos países e o universo simbólico das culturas. Desse modo, essa narrativa encena as complexas e quase sempre contraditórias relações que se estabelecem entre o apego às origens, como elemento constitutivo da própria subjetividade, e certo "desenraizamento" que orienta - mas que também parece desnortear essa mesma experiência subjetiva na atualidade.

Nascidos, como Rushdie, no conturbado contexto da declaração de independência indiana, a trajetória sinuosa e instável desses personagens transcorrerá em meio às intensas transformações verificadas a partir de meados do século 20 , demarcando o cenário inaugural da contemporaneidade.

Transparece, através da escrita ficcional, um momento histórico especialmente dinâmico, incerto, emoldurado, entre outros fatores, por movimentos anticolonialistas, pela Segunda Guerra Mundial, pela difusão da contracultura e da estética pop, e, ainda, pela revolução tecnológica e pela agudização dos conflitos étnico-religiosos. Essa conjuntura é delineada, ao longo de todo o romance, quando vemos enredarem-se em suas páginas, para citar apenas alguns dos vários exemplos, os episódios que antecederam o assassinato de Indira Gandhi, por dois de seus guarda-costas, devotos da religião Sikh, em represália ao endurecimento das relações da primeira-ministra com essa comunidade, culminando na chacina de mais de quinhentos fiéis amotinados no santuário de Amritsar, transformado em quartel-general dos movimentos separatistas. Da mesma forma, teremos inúmeras referências aos massacres ocorridos durante as lutas de independência, e, especialmente, por ocasião da Partition, que daria origem, em 1947, tanto à Índia quanto ao Paquistão, fazendo arrastar, até os dias atuais, numerosos conflitos étnicos, religiosos, políticos e econômicos que proliferam ao norte da Índia, aguçados na região da Caxemira, cuja administração, bipartida 
primeiramente entre os dois países, e, mais tarde, também com a China, resulta em confrontos violentos frequentemente tratados pelo narrador de $O$ chão que ela pisa.

No decorrer da narrativa, o agitado cenário da Índia contemporânea, com seus famigerados contrastes socioeconômicos, com suas interações multidialetais, sua geografia peculiaríssima, sua incomum diversidade religiosa, enfim, com sua intrincada configuração identitária, é continuamente entretecido com a memória de uma Índia colonial, cujas marcas parecem impregnar toda a história posterior do subcontinente. ${ }^{8}$ Especificamente no romance, essa memória estará vinculada à história particular da família de Ormus Cama, cuja trajetória esteve, desde sempre, vinculada às relações materiais ou simbólicas estabelecidas com os antigos valores coloniais, e, principalmente, ao posicionamento ideológico de seu patriarca, Darius Xerxes Cama. Esse posicionamento, representado pelo cultivo ostensivo de hábitos e costumes da "civilização britânica", 9 da qual foi extremado defensor durante grande parte de sua vida, parece favorecer a construção de um imaginário familiar que, de maneiras diversas, e em tempos diferenciados, será responsável pela gradativa migração de todo o grupo para Londres, à exceção do próprio Darius, ironicamente condenado a viver e morrer distante da "Mãe Inglaterra", expressão que ele, em seu fervor político, gostava de usar.

No romance, são igualmente abundantes as referências a eventos que marcaram os sucessivos governos norte-americanos e sua participação nos destinos de outras nações, com predomínio da era Kennedy e Reagan. Nessa trilha, muitos dos acontecimentos que pontuaram as relações internacionais no mundo contemporâneo, como as guerras da Indochina e do Vietnã, a invasão do Tibete, a Guerra Fria, farão parte, direta ou indiretamente, da vida dos personagens de $O$ chão que ela pisa, e, muitas vezes, serão testemunhados pelas lentes do fotógrafo Rai Merchant. É também importante ressaltar, nesse contexto, o uso que faz o romance do surgimento dos Estados Unidos da América como

\footnotetext{
${ }^{8}$ Além da Índia, o Paquistão, o Bangladesh, e, às vezes, também o Nepal e o Butão, são incluídos no que se costuma chamar "subcontinente indiano". Essa denominação, normalmente, se refere a áreas de dimensões significativas que apresentam algum traço geológico unificador e/ou algum elemento que componha uma espécie de fronteira natural - nesse caso, uma placa tectônica e a cordilheira do Himalaia; mas, politicamente, essas áreas são consideradas como parte de um continente. Assim, dependendo da abordagem, a Europa ou a Ásia podem ser referidas como subcontinentes da Eurásia; a América do Norte e a América do Sul podem ser entendidas como subcontinentes da América, e assim por diante. Trata-se, portanto, de uma terminologia relativa; e, embora menos comum, há também a possibilidade de se aplicar essa designação com foco geopolítico a regiões ou sub-regiões que apresentam características históricas, étnicas ou culturais muito diversas em relação ao seu continente de pertencimento político, como é o caso, por exemplo, do Oriente Médio.

${ }^{9}$ RUSHDIE. O chão que ela pisa, p. 46.
} 
superpotência no século 20, principalmente no campo cultural. Esse aspecto será o fio condutor da trajetória dos três personagens centrais, cuja trama se desenvolve no centro irradiador da contracultura e da pop art, com incontáveis referências a episódios e ícones desses universos.

Desse modo, conhecidas personalidades circularão pelo chão de papel de Salman Rushdie, ora por meio da simples menção, ora pela apropriação de características físicas ou dados biográficos, ou, ainda, pela remissão a obras, pela paródia de textos e célebres composições musicais, pela homenagem ou pela desconstrução implacável de ídolos do cenário artístico norte-americano e britânico da segunda metade do século passado. Muitas vezes transportados para espaços e tempos diferentes daqueles em que de fato existem ou existiram, veremos, lembrando apenas alguns exemplares da constelação evocada em $O$ chão que ela pisa, os Beatles e Elvis Presley; Rolling Stones e Bob Dylan; Peter Paul and Mary, Manfred Man, Lou Reed, Jim Morrison, The Temptations e Madonna; Andy Warhol e Queen. Outras vezes, será possível identificar, num único personagem, um amálgama do escritor martinicano Aimé Césaire e do artista plástico nova-iorquino Jean-Michel Basquiat. Em todos os casos, evidencia-se, aos poucos, uma das mais significativas marcas da contemporaneidade, que é o culto à fama, à celebridade instantânea e, muitas vezes, efêmera.

Finalmente, ainda nesse âmbito, cumpre assinalar a importância desse referencial, que será aproveitado por Rushdie também na idealização da cantora Vina Apsara e do guitarrista Ormus Cama, a partir das sombras dos baluartes hippies Janis Joplin e Jimi Hendrix. A trajetória desses personagens será, assim, emblemática no que diz respeito à ideia de um sistema midiático que, ao mesmo tempo, erige e consome suas legendas, e cuja ação tem efeitos cada vez mais globalizados. É nessa rede infinda de apropriações que a banda de rock V.T.O., encabeçada no romance por esses dois personagens, pode ser aproximada, pela trajetória de sucesso meteórico e por um jogo linguístico, à banda irlandesa U2, que, entre inúmeras alusões, terá incluída, em uma passagem da narrativa, a letra da canção "The ground beneath her feet", que também nomeia o livro. ${ }^{10}$

Essa configuração reticular, muitas vezes caótica, parece refletir, na escrita, certa crise de fronteiras - geográficas, políticas, disciplinares, culturais - que se projeta também no imaginário social, permitindo, a partir da ficção, problematizar as diferentes formas de se

\footnotetext{
${ }^{10}$ The ground beneath her feet foi escrita numa espécie de parceria entre Rushdie e os componentes do U2, agregando-se ao enredo do romance; a canção faz parte, também, da trilha sonora do filme The million dollar hotel, de Wim Wenders (122 min. EUA, Alemanha, Reino Unido, 2000), que tem roteiro de Nicholas Klein e Bono Vox, vocalista da banda.
} 
estar no mundo - no caso do romance, um mundo marcado por conflitos oriundos da inserção desigual ou da exclusão dos indivíduos nos processos de interação social, e pela consequente perda de referências identitárias. O chão que ela pisa apresenta-se, pois, como uma narrativa conectada a essa conjuntura em particular, captando, segundo o narrador do romance, "um modo de vida no momento de seu aniquilamento", ${ }^{11}$ isto é, pelo menos no âmbito específico do romance, o momento agônico da modernidade.

Em princípio, esse emaranhado de referências e a profusão de informações e discursos diversificados sugerem um texto também prolixo, enciclopédico e fragmentado, o que, em certa medida, é um fato, no entanto, Rushdie irá potencializar a representação das múltiplas circunstâncias históricas que ambientam a narrativa de modo a que o enredo se organize e se desdobre em torno de uma única chave. Trata-se de uma imagem terrível, que atua, pois, como referência metafórica desse mundo em colapso. Através da imagem do terremoto, dos abalos sísmicos, dos tremores de terra, dos desmoronamentos, $O$ chão que ela pisa remete a um mundo extratextual também repleto de falhas, deslizamentos, entrechoques.

Em sentido estrito, um terremoto constitui uma ocorrência tectônica, ou seja, um tipo de movimento da crosta terrestre. Por definição, trata-se de um efeito da movimentação das camadas sólidas exteriores da superfície da Terra, em consequência de forças endógenas, derivando uma arquitetura peculiar do solo e do subsolo. Diz respeito, pois, ao dinamismo das forças que interferem no movimento dessas camadas. Como resultado dessa interferência, verifica-se o aparecimento de dobras, falhas, fraturas, lençóis de arrastamento, entre outros feitios, de modo geral, entendidos como deformações da crosta. Ao abrir suas fissuras ao longo de toda a narrativa, a imagem do terremoto remete, ao mesmo tempo, a um espaço acidentado e à mobilidade dos processos identitários que nele se delineiam. Concentra-se, assim, nas imagens do fenômeno geológico, a desestabilização das diversas noções de pertencimento e dos valores de sustentação de certo imaginário sociopolítico e cultural, como a nacionalidade, o valor pátrio, o território, a noção de cidadania. É assim que o chão - em seu sentido literal e figurado, dentro e fora do texto - mostra-se deslizante, inseguro, prestes a ceder à mínima pressão.

Nesse sentido, pode-se dizer que o texto de Rushdie faz as vezes de um sismógrafo, e, como esse instrumento destinado a representar graficamente a atividade da crosta terrestre, constrói uma espécie de "escrita do sismo". Ao registrar os abalos e tremores que assolam o mundo na atualidade, sempre devastadores, seja em sua ocorrência física, concreta, seja em

\footnotetext{
${ }^{11}$ RUSHDIE. O chão que ela pisa, p. 20.
} 
seus efeitos simbólicos, também essa escrita se apresenta repleta de lacunas, interrupções, dobras, prestando-se, portanto, a uma melhor compreensão dos movimentos de alternância entre desagregação e reconstituição do mundo contemporâneo, definido, no romance, a partir do chão oscilante, da terra convulsionada, do solo movediço que muda as fronteiras de lugar, extingue-as sob os escombros, e impõe a contínua redefiniç̧ão dos territórios sobre um espaço físico arruinado.

Em vários momentos, no decorrer do enredo, Rai Merchant, o narrador de Rushdie, contempla diferentes pontos de vista, sob a forma de livres fluxos de consciência colocados frente a um interlocutor imaginário, e alinha os sismos geológicos no mesmo diapasão das transformações político-sociais:

Para muitos observadores do terceiro mundo, parece evidente por si que os terremotos são a nova política hegemônica, o instrumento com o qual os superpoderes fazedores de terremotos pretendem sacudir e quebrar as economias emergentes do Sul, do Sudeste, da Borda. ${ }^{12}$

No rastro dessa discussão, não é demais lembrar que o processo de globalização reflete, por um lado, uma ideia de universalização, mas, por outro, em contínua tensão, atua como instrumento de estratificação social, promovendo a centralidade de certas instâncias de poder político e econômico - instâncias que podem ser indistintas, em certos momentos, de nações, países, governos -, as quais prescrevem prioridades para o mundo periférico, o que tende a reduzir as chances de equidade no cenário mundial. Insinua-se, então, a contrapartida das minorias diante dos "superpoderes dos fazedores de terremotos", na condição de coparticipantes de uma "nova ordem global", construindo possibilidades de produzir seus próprios tremores, de desestabilizar uma política hegemônica, forçando a negociação e a reconfiguração de territórios. Assim, conseguem minar e fazer ruir os blocos monolíticos dos novos "Impérios", pensados, aqui, "não como um regime histórico nascido da conquista, e sim como uma ordem que na realidade suspende a história", ${ }^{13}$ como forma paradigmática de biopoder, que, por vias diversas e difusas, quase imperceptíveis, estabelece, entre outros referenciais, a regulação das identificações desejáveis para a manutenção dos Estados modernos. ${ }^{14}$ Seria, porém, exatamente essa manutenção que se encontraria em perigo no

\footnotetext{
${ }^{12}$ RUSHDIE. O chão que ela pisa, p. 553-554.

${ }^{13}$ HARDT; NEGRI. Império, p. 14-15.

${ }^{14}$ Considerem-se, nesse aspecto, também as reflexões de Zygmunt Bauman, para quem a ideia de uma "nova ordem global" implica a imagem de uma "desordem global", que refletiria a "consciência (facilitada, mas não necessariamente causada pela morte súbita da política de blocos) da natureza essencialmente elementar e contingente das coisas que anteriormente pareciam tão firmemente
} 
contexto contemporâneo, com um visível realinhamento de forças que, se ainda não aponta para o apagamento dos limites territoriais, assinala pelo menos duas direções comuns no cenário atual: por um lado, a extremada defesa desses limites, a partir da disseminação de um imaginário xenofóbico, por exemplo, o que, pode-se supor, revela também alguma fragilidade; por outro, a contínua substituição e/ou ressignificação dessas coordenadas territoriais, com o surgimento e multiplicação de processos identitários alternativos, como a formação de comunidades ou mesmo a afirmação de governos paralelos dentro dos limites oficialmente instituídos.

Mesmo considerando que as ciências - particularmente as ciências sociais - vêm tratando dos abalos por que têm passado as noções de "nação", desde as suas várias definições históricas, milenares, e o surgimento dos Estados modernos, até a ideia ampliada de nacionalidades eletivas - de livre escolha por um pertencimento geopolítico, de gênero, de orientação sexual -, caberia observar que tais abalos, esses metafóricos e perigosos terremotos, com seu potencial desestruturante, se desenham a partir de uma questão central: a que se pertence, que vínculos se pode estabelecer com o outro num mundo cujas fronteiras estão se desfazendo? Essa questão, tratada aqui de maneira simplificada, deixa entrever as dificuldades que se colocam para o debate em torno dos inúmeros territórios de adesão - nos quais se incluem a cidade, o país natal, com as línguas e culturas que ainda os mantêm defensáveis como valor de pertencimento, como algo a que se deseja estar vinculado -, as incontáveis "pátrias imaginárias" e continuamente imaginadas.

Em meio a esses múltiplos territórios, muitos dos quais ameaçados, a literatura, como espaço até agora capaz de explicitar as controvérsias e as contradições do mundo civilizado, se apresentaria como um solo dos mais acolhedores, a despeito de seu potencial de abalo - ou exatamente em razão desse potencial -, para esses sujeitos que, inseridos na experiência contemporânea, não encontram outro modo de estar no mundo senão o desenraizamento e, consequentemente, as identificações provisórias, superpostas, itinerantes.

Dentro e fora do texto, na superfície da página de papel e na superfície do solo, não como simples espelhamento, mas como processos intercomunicantes, operam-se as mudanças, as renovações, as transformações profundas, muitas vezes de forma abrupta, violenta, como se fossem inevitáveis efeitos de um sismo, como os muitos mencionados no romance:

controladas ou pelo menos "tecnicamente controláveis"” (BAUMAN. Globalização: as conseqüências humanas, p. 65). Importante, ainda, para essa abordagem: FOUCAULT. Microfísica do poder. 
Todo mundo lê jornal, certo, portanto, não tenho que explicar com muitos detalhes como o mundo mudou nestes últimos anos, a súbita perda de altura do Himalaia, a fenda ao longo da fronteira Hong Kong-China que transformou os Novos Territórios em uma ilha, o afundamento da ilha Robben, a emergência da Atlântida em Santorina-Thera nas Cíclades do extremo sul, a transformação do rock'n'roll em uma arma que expulsou de seu esconderijo o ditador fugitivo do Panamá (...). Esses terremotos de fronteira são a maravilha da era, não são? Você viu a falha que simplesmente rasgou toda a cortina de ferro? "Inesquecível" não chega nem perto de descrever. E depois que os chineses abriram fogo em Tiananmen, você viu o penhasco que se abriu ao longo de toda a extensão da Grande Muralha da China ${ }^{15}$

Entende-se, nesse universo discursivo, que a escrita de Salman Rushdie provém de uma condição fronteiriça, reforçando uma espécie de "imaginário migrante" e dele se nutrindo. É a partir desse imaginário que se pode pensar as noções de "errância", "nomadismo", "exílio", experiências a que tanto o autor quanto seus personagens sempre estiveram expostos. É provável que essa escrita possa, assim, trazer à luz algumas relações entre processos identitários e suas referências geopolíticas territoriais ainda que se trate de referências falidas, em crise, desacreditadas no mundo atual.

No caso de Rushdie, a experiência de exílio tem início em 1961, quando, voluntariamente, voa, "muito animado", para o Ocidente, indo estudar na cidade medieval de Rugby, no condado de Warwickshire, Inglaterra, procedimento usual entre as famílias abastadas da Índia recém-independente. A partir de 1988, com a publicação de Os versos satânicos, esse exílio tomaria outras conotações. A Índia foi o primeiro país a banir o polêmico romance, "proscrito sem obedecer ao devido processo estipulado para essas questões, banido, antes de entrar no país" e, num tom passional, algo melodramático, como ele mesmo admite, Rushdie dará uma dimensão do significado desse episódio que o tornaria persona non grata em seu próprio país:

Nada nos meus anos da peste, a década sombria que se seguiu à fatwa de Khomeini, me machucou mais que essa ruptura. Eu me sentia como um amante descartado, abandonado com seu amor não correspondido, intolerável. Dá para medir o amor pelo tamanho do buraco que ele deixa para trás. ${ }^{16}$

${ }^{15}$ RUSHDIE. O chão que ela pisa, p. 502.

${ }^{16}$ RUSHDIE. Cruze esta linha: ensaios e artigos (1992-2002), p. 184. Na ordem islâmica, uma fatwa constitui um pronunciamento, com valor de lei, normalmente emitido por um especialista em assuntos religiosos, de modo a esclarecer uma questão que se apresenta obscura à jurisprudência muçulmana. Tem, nesse caso, certa semelhança com as bulas emitidas pelo Vaticano, sob a chancela pontificial, com instruções, orientações e vetos aos fiéis católicos. Especificamente, a fatwa decretada pelo imã iraniano, o Ayatullah Al-Odhma Assayed Ruhollah Khomeini, em14 de 
Assim, o instrumento da moderna diplomacia internacional que permite a um Estado declarar judicialmente que alguém é persona non grata reveste de legalidade aquilo que, fundamentalmente, constitui uma arbitrariedade. ${ }^{17}$ Nesse caso, ressalta-se, por um refinamento civilizatório, o significado do espaço territorial, tanto para quem o resguarda ou nele se ampara quanto para quem dele foi deportado ou a ele teve o acesso interditado. Ao longo de sua carreira como escritor, Rushdie parece reconhecer um elo entre esse acontecimento e seu destino literário:

Desde então, meus personagens freqüentemente voam da Índia para o Ocidente, mas, romance após romance, a imaginação do autor ainda volta para casa. Isso, talvez, é o que significa amar um país: que a forma dele é também a sua, a forma como você pensa, sente e sonha. Que você nunca consegue realmente abandonar. ${ }^{18}$

Tomando, então, não o exílio de Rushdie, mas a representação da experiência de exílio que ele constrói em $O$ chão que ela pisa, é possível apreender alguns aspectos da contínua construção/desconstrução de identidades nos espaços deslizantes que constituem o universo narrativo do romance. No chão recriado pelo escritor, um chão movente, incerto, polimórfico, suas criaturas - também elas em permanente transformação - irão encenar relações que se conformam apenas e tão-somente no espaço-tempo do exílio.

Às consecutivas experiências de desterritorialização e reterritorialização do espaço corresponderiam, nessa perspectiva, processos similares de desconstrução e reconstrução de subjetividades. O que se pode pensar é que as figuras do migrante, do nômade, do errante, do expatriado, do degredado, do exilado recorrentes no texto de Rushdie tornam-se, assim, responsáveis pela construção de um imaginário social marcado pela ideia de transitoriedade, de não fixidez, de desenraizamento. Apresenta-se, desse modo, uma escrita produzida no interstício, talvez ensejando alguma compreensão desse espaço ambivalente que conforma a

fevereiro de 1989, condenou Salman Rushdie à morte, e, embora o Irã tenha se eximido formalmente da aplicação da pena, em 1998, a partir de um acordo com o governo britânico, líderes e fiéis das linhas radicais muçulmanas continuamente reafirmam sua irrevogabilidade.

${ }^{17}$ Esse recurso foi instituído em 18 de abril de 1961, pelo artigo 9 da Convenção de Viena sobre as Relações Diplomáticas, aberta à assinatura de "todos os Estados-Membros das Nações Unidas ou de uma organização especializada bem como dos Estados-Partes no Estatuto da Corte Internacional de Justiça e de qualquer outro Estado convidado pela Assembléia Geral das Nações Unidas a tornar-se Parte na Convenção". Inicialmente limitado a membros de missões diplomáticas, é hoje utilizado - normalmente com valor simbólico - por qualquer órgão de representação pública, sendo extensivo a qualquer cidadão. O texto da Convenção encontra-se disponível, na íntegra, no site do Ministério das Relações Exteriores do Brasil, em: $<$ http://www2.mre.gov.br/dai/m_multidiplo.htm>.

${ }^{18}$ RUSHDIE. Cruze esta linha: ensaios e artigos (1992-2002), p. 183. 
contemporaneidade. Ao encenar uma crise geonômica, ou seja, ao representar certa desestabilização das próprias leis que regem as modificações do solo terrestre, o texto de Rushdie problematiza, também, os processos de subjetivação, interpelando as identidades estanques, pretensamente consolidadas a partir de uma concepção de mundo assentada sobre uma ilusória estabilidade. É assim que as noções de limite e fronteira se mostram, na narrativa, como construtos culturais que demarcam o espaço geográfico e as relações entre os sujeitos: demarcam, separam, distinguem, mas, ao mesmo tempo, se mantêm porosas o bastante para que o trânsito se estabeleça, para que a interlocução seja possível, para que as marcas identitárias se indaguem, se mesclem, se renovem mutuamente. Nesse processo, noções como "pátria", "país", "nação", “cidade” dão-se a conhecer em seu aspecto polissêmico, pois que são construídas em territorializações provisórias, por sujeitos em estado de mobilidade, que se encontram sempre de passagem e estão sempre em relação com o outro, seja ele material ou simbólico.

Em O local da cultura, Homi Bhabha analisa, na perspectiva da crítica pós-colonial, os processos de reterritorialização resultantes do embate entre sistemas culturais distintos, em que se observa a emergência de formas híbridas de subjetivação. Curiosamente, é nessa coletânea de ensaios que Bhabha torna público o seu reconhecimento de que os romances de Salman Rushdie foram responsáveis por muitas das ideias desenvolvidas em sua produção crítica sobre o espaço migrante e de minoria. Por conseguinte, o conceito de "espaço migrante" interessa particularmente ao estudo de toda a obra de Rushdie, por configurar-se como uma espécie de zona de "destituição étnica", em que se estabelece, ou se evidencia, uma nova ordem mundial, um "terceiro espaço", no qual as experiências intersubjetivas e coletivas de nação (nationness), o interesse comunitário ou o valor cultural são, forçosamente, negociados. ${ }^{19}$ Essa zona de destituição étnica, em $O$ chão que ela pisa, talvez seja confirmada por meio de diferentes formas de atravessamento de fronteiras, colocando à prova os mecanismos, os dispositivos sociais, políticos, econômicos - ou, como diz o narrador, “os guardas de fronteira" - que, perversamente, pretendem regular o fluxo dos sujeitos e de suas ideias.

Via de regra, os diversos modos de regulação social mostram-se a serviço de uma configuração desigual de forças, mas, de modo geral, não impedem as negociações e trocas entre as diferentes culturas. A fronteira constituiria justamente o espaço de articulação de múltiplas vozes e, nesse espaço, a linguagem, como mediação e substância de interação

\footnotetext{
${ }^{19}$ BHABHA. O local da cultura, p. 11.
} 
dinâmica, pode revelar diferentes aspectos das relações interculturais. Todo texto traria, por isso, alguma possibilidade de compreensão dos encontros e confrontos entre grupos diversos, entre sujeitos diversos. Tal modelo teórico aponta para a fronteira "como um espaço conceitual que incita negociações culturais entre composições híbridas e espaços intersticiais, isto é, uma construção complexa, interativa e, freqüentemente, contenciosa de identidades e identificações". ${ }^{20}$ Assim entendida, é importante frisar que a fronteira não poderia configurar somente o lugar de atravessamento, mas própria travessia; não o local de encontro, mas o próprio encontro, conflituoso, contestatório, tensional, transformador: interações operadas pela linguagem, como forma subjetiva de exposição, de defesa, de indagação de outro a outro. Não se pode esperar, por isso, tratar-se do encontro de identidades já construídas, monolíticas, impermeáveis, mas de alteridades em situação de enfrentamento muitas vezes doloroso e traumático.

Mas é preciso dizer, ainda, que $O$ chão que ela pisa pode ser lido também como uma história de amor, com cenas de ciúmes, juras desesperadas, infidelidades, perdas. No entanto, o que poderia ser apenas um relato das agruras de um clássico triângulo amoroso, protagonizado por Rai, Ormus e Vina, apresenta-se como encenação das relações intersubjetivas que tentam se firmar na atualidade. Assim, esses três personagens se debatem, cada um a seu modo, permanentemente em luta com a ideia fantasmática de uma origem remota. Para eles, sempre é possível partir de um ponto qualquer em que estejam; sempre é possível romper os laços invisíveis com a cidade natal, com as ruas da infância, com a família; contudo, essa ruptura parece nunca se consumar de modo absoluto, e será inevitável olhar para trás, como se apenas no terreno da memória pudesse haver algum chão firme. Porém, como na narrativa mítica de Orfeu, esse gesto, esse olhar retroativo, impõe o risco da perda e, num percurso metafórico, eles irão também cruzar a linha entre o passado e o presente. Ao retomar a lenda de Orfeu para construir seu texto, Rushdie transpõe também a fronteira entre os tempos e coloca essa narrativa em interação com outros textos, com outras tradições, com outros discursos, reendereça o mito a um novo circuito de interpretação, a um novo protocolo de leitura dos signos do passado, permitindo-nos pensá-los inseridos num mundo já desvencilhado do tempo e espaço primordiais, um mundo que, em sua realidade cambiante, requer um esforço cada vez maior de entendimento.

Em $O$ chão que ela pisa, Rushdie trata desse mundo vário, diverso, um mundo construído pelo olhar também vário e diverso de seus personagens - Rai Merchant, Ormus

\footnotetext{
${ }^{20}$ VIEIRA. A fronteira como modelo teórico: literatura e experiência judaica no Brasil, p. 165.
} 
Cama e Vina Apsara, entre dezenas e dezenas de criaturas a coexistir nas páginas do romance, configurando uma teia de pequenas histórias entrelaçadas, enoveladas na grande história mítica, ancestral, de Orfeu, Eurídice e Aristeu. Uma história de amor como pode ser uma história de amor nesses tempos incertos. Ao reeditar o mito órfico, Rushdie redireciona o olhar - o seu, o do leitor - para outros mitos, outras narrativas, que se conformam, cotidianamente, no mundo da cultura de massas, do consumo, das guerras, das disputas políticas contemporâneas, no curso do "bizarro século 20 " ou do perplexo século 21, no Oriente e no Ocidente, e, principalmente, na fictícia porém, intransponível membrana que separa esses dois hemisférios.

Numa espécie de paráfrase do mito antigo, será pela escrita que o narrador Rai Merchant fará seu rito de expurgo. Após a morte da mulher amada - e também a do amigo e rival, Ormus -, seria impossível não olhar para trás, como fez Orfeu, perscrutar o passado e narrar a história. Até então, tudo o que há é o terreno amorfo da memória, sobre o qual esse personagem não tem controle algum. Resta-lhe, então, apropriar-se desse terreno, lavrá-lo, dar-lhe a forma do inteligível. A escrita, simulando um relato de memórias, se apresenta, nesse momento, como força impositiva, inescapável, e, ao iniciá-lo, o personagem se mostra pronto a pagar o passe para a travessia, e mergulhar no que ele entende ser um "submundo de tinta e mentiras", e assim anuncia: "E aqui estou às portas do inferno da linguagem, com um cachorro latindo e um barqueiro esperando, com uma moeda para pagar a passagem debaixo da língua." ${ }^{21} \mathrm{O}$ "inferno da linguagem" parece remeter, nessa passagem, a um campo de enfrentamento do sujeito consigo mesmo, repisando os passos do herói grego em sua descida iniciática ao Hades.

É possível que, devido à sua riqueza simbólica - ligada à ideia de morte e renascimento -, o mito de Orfeu venha se mostrando como um dos mais resistentes ao correr dos tempos, suscitando inúmeras recriações em regimes semióticos diversos. ${ }^{22}$

${ }^{21}$ RUSHDIE. O chão que ela pisa, p. 28.

${ }^{22}$ Não seria possível, neste ensaio, inventariar essas obras. Cito apenas alguns poucos exemplos, no intuito de dar uma dimensão da força dessa narrativa em outras culturas, já tão distanciadas do contexto de surgimento do mito. L'Orfeo (La Favola d'Orfeo), de Claudio Monteverdi, estreada em 1607, na comuna italiana de Mântua (Mantova), capital da província de mesmo nome, onde teria nascido Virgilio, em 70 a.C., é a mais antiga ópera conservada integralmente até os nossos dias. Mencione-se também, de Christoph Willibald Ritter von Glück, Orfeo ed Euridice (1762), retomada em uma passagem do romance de Rushdie (1999a, p. 19-20); e, no século XIX, de Jacques Offenbach, Orphée aux Enfers. O mito foi tema para o balé Orpheus und Eurydice, de Heinrich Schütz, em 1638 e, na música, foi retomado por Telemann (Orpheus, de 1726), por Liszt, no poema sinfônico Orpheus, de 1848, e ainda por Stravinsky (Orpheus, 1947), entre dezenas de outros compositores. Entre as realizações cinematográficas, há duas criações de Jean Cocteau: 
O chão que ela pisa insere-se, assim, numa longa série de releituras, incluindo, na literatura, desde as clássicas Odes píticas, de Píndaro, e o orfismo platônico - expresso pela noção de imortalidade da alma (República, Crátilo, Górgias) -; ou as Metamorfoses de Ovídio e mesmo o poema de Virgílio (Geórgicas), que Rushdie privilegia como intertexto em sua narrativa; o mito marca ainda o romantismo alemão, com Novalis, em seus versos e fragmentos de Hinos à noite; e reaparece, em uma de suas mais notáveis versões, em Invenção de Orfeu, do brasileiro Jorge de Lima. Entre as inúmeras recriações contemporâneas, a narrativa mítica foi retomada também por Vinicius de Moraes e Antonio Carlos Jobim, celebrizada em Orfeu da Conceição: tragédia carioca, em montagem teatral de 1956, transposta para o cinema, por Marcel Camus, em 1959, por Cacá Diegues em 1999.

Assim como a peça de Vinicius de Moraes recontextualiza a narrativa mítica, situando a ação em uma favela carioca, adotando uma linguagem marcadamente coloquial, e com a recomendação explícita de que os atores, via de regra, fossem negros, O chão que ela pisa irá servir-se da trágica história de Orfeu e Eurídice para trazer à tona as novas configurações do afeto no mundo contemporâneo. No romance, também o amor se esfacela no terreno impactado por transformações que colocam em questão, cotidianamente, os relacionamentos interpessoais; também ele estará sujeito a migrar entre os continentes, a metamorfosear-se em simulacros esvaziados pela mídia, mercantilizado pela indústria cultural, oferecendo-se em incontáveis versões no Olimpo virtual das celebridades. Apenas na memória do narrador, ou em sua tentativa de cristalizar essa memória pela escrita, é que o amor encontra forma de expressão. Trata-se, mesmo assim, de uma memória contaminada pelo tempo caótico focalizado por Rushdie, um tempo fragmentado, fraturado, assim como é também o espaço desfigurado por um terremoto. Essa memória é, por isso, sempre fracionada, sem contornos evidentes, instável. Como nos versos de Drummond, que servem de epígrafe a este ensaio, perpassa todo o romance o trabalho da memória, como arquivo imperfeito, esfumado, espaço construído entre "o talvez e o se". E é a partir da encenação desse espaço intervalar, apenas vislumbrado entre as formas do passado e do presente, que Salman Rushdie põe sob nossos

Orphée (1949) - Cocteau também já havia escrito, em 1926, uma peça homônima - e Le testament d'Orphée (1959); no Brasil, lembro a recente película de Cacá Diegues, Orfeu (Brasil, 1999). Nas artes plásticas, o universo órfico vem sendo continuamente representado - nas esculturas de Canova, Rodin, Carl Miles; na pintura de Dürer (Death of Orpheus, 1494); Poussin (Orpheus and Eurydice, 1650); Moreau (Orpheus, 1865); Waterhouse (Nymphs finding the Head of Orpheus, 1900) - ou de alguma forma evocado, por exemplo, pelo "cubismo órfico" de Guillaume Apollinaire (Le Béstiaire ou Cortège d'Orphée, 1911) e sua irradiação nas obras de Francis Picabia, Robert Delaunay e Marcel Duchamp. 
pés um chão de ilusória estabilidade, no qual sua escrita vem se afirmando, às avessas, com a "autoridade" multivalente que somente à ficção pode ser conferida.

\begin{abstract}
Considering the metaphorical representation of the seismic natural phenomena, understood as analog index of the identifying processes portrayed in the contemporary space and time, this study analyzes the novel The ground beneath her feet ( $O$ chão que ela pisa), by Salman Rushdie, pointing to the constitution of a "migrant imaginary" like a symbolic space of the identity affiliation.
\end{abstract}

\title{
KEYWORDS
}

Border area, Earthquake, Identity

\section{REFERÊNCIAS}

ANDRADE, Carlos Drummond de. Claro enigma. Rio de Janeiro: Record, 2001.

BAUMAN, Zygmunt. Globalização: as conseqüências humanas. Trad. Marcus Penchel. Rio de Janeiro: Jorge Zahar Editor, 1999.

BHABHA, Homi K. O local da cultura. Trad. Myriam Ávila; Eliana Lourenço de Lima Reis; Gláucia Renate Gonçalves. Belo Horizonte: Editora UFMG, 2005.

BORGES, Jorge Luis. Obras completas. Trad. vários autores. São Paulo: Globo, 1999. v. 2.

CALVINO, Italo. Seis propostas para o próximo milênio. 2. ed. Trad. Ivo Barroso. São Paulo: Companhia das Letras, 1990.

DELEUZE, Gilles; GUATTARI, Félix. Kafka. Por uma literatura menor. Trad. Júlio Castañon Guimarães. Rio de Janeiro: Imago, 1977.

FOUCAULT, Michel. Microfísica do poder. 15. ed. Trad. Roberto Machado. Rio de Janeiro: Graal, 2000.

FOUCAULT, Michel. As palavras e as coisas. Uma arqueologia das ciências humanas. 8. ed. Trad. Salma Tannus Muchail. São Paulo: Martins Fontes, 2002.

HARDT, Michael; NEGRI, Antonio. Império. Trad. Berilo Vargas. Rio de Janeiro: Record, 2005.

MORAES, Vinicius de. (1974). Vinicius de Moraes - poesia completa e prosa. 2. ed. único. Rio de Janeiro: Nova Aguilar, 1986. v. único.

RAJAGOPALAN, Kanavillil. Quando o humor azeda: o episódio Rushdie em retrospectiva. Estudos Avançados, IEA/USP, v. 10, n. 27, p. 115-126, 1996. 
RUSHDIE, Salman. Imaginary homelands. Essays and criticism (1981-1991). London: Granta Books, 1992.

RUSHDIE, Salman. O chão que ela pisa. Trad. José Rubens Siqueira. São Paulo: Companhia das Letras, 1999.

RUSHDIE, Salman. Cruze esta linha: ensaios e artigos (1992-2002). Trad. José Rubens Siqueira. São Paulo: Companhia das Letras, 2007.

SANTIAGO, Silviano. O cosmopolitismo do pobre: crítica literária e crítica cultural. Belo Horizonte: Editora UFMG, 2004.

VIEIRA, Nelson. A fronteira como modelo teórico: literatura e experiência judaica no Brasil. In: NAZARIO, Luiz; NASCIMENTO, Lyslei (Org.). Estudos judaicos: Brasil. Belo Horizonte: Faculdade de Letras, FALE/UFMG, 2007. p. 161-71. 